\title{
Introduction: International Research Ethics Education
}

\author{
Joseph Millum and Barbara Sina \\ National Institutes of Health
}

\begin{abstract}
NIH's FOGARTY INTERNATIONAL Center has provided grants for the development of training programs in international research ethics for low- and middle-income (LMIC) professionals since 2000. Drawing on 12 years of research ethics training experience, a group of Fogarty grantees, trainees, and other ethics experts sought to map the current capacity and need for research ethics in LMICs, analyze the lessons learned about teaching bioethics, and chart a way forward for research ethics training in a rapidly changing health research landscape. This collection of papers is the result.
\end{abstract}

KEY WORDS: research ethics, education, Fogarty International Center

Received: March 4, 2014; revised March 6, 2014

$\mathrm{O}$ VER THE LAST COUPLE OF DECADES, THE amount of health research conducted in low- and middle-income countries (LMICs) has dramatically increased. In response to the corresponding need for research ethics expertise, the NIH's Fogarty International Center has provided grants for the development of training programs in international research ethics for LMIC professionals since 2000. Twenty programs have now graduated approximately 600 long-term trainees from 74 LMICs. The participants train others in research ethics, lead ethical review of research protocols, develop ethical guidance for research, and contribute to national and international debates on issues in research ethics.

Drawing on 12 years of research ethics training experience, a group of Fogarty grantees, trainees, and other ethics experts sought to map the current capacity and need for research ethics in LMICs, analyze the lessons learned about teaching bioethics, and chart a way forward for research ethics training in a rapidly changing health research landscape. This collection of papers-published in two special issues of JERHRE-is the result (Box 1).
BOX 1. The Fogarty International Center Research Ethics Education Collection.

\begin{tabular}{|c|c|}
\hline \multicolumn{2}{|c|}{ JERHRE 8.5} \\
\hline $\begin{array}{l}\text { Joseph Millum, Christine } \\
\text { Grady, Gerald Keusch, and } \\
\text { Barbara Sina }\end{array}$ & $\begin{array}{l}\text { Introduction: The Fogarty } \\
\text { International Research } \\
\text { Ethics Education and } \\
\text { Curriculum Development } \\
\text { Program in Historical } \\
\text { Context }\end{array}$ \\
\hline Sana Loue and Bebe Loff & $\begin{array}{l}\text { Is There a Universal Under- } \\
\text { standing of Vulnerability? } \\
\text { Experiences with Russian } \\
\text { and Romanian Trainees } \\
\text { in Research Ethics }\end{array}$ \\
\hline $\begin{array}{l}\text { Martin A. Strosberg, Eugenijus } \\
\text { Gefenas, Sana Loue, and } \\
\text { Sean Philpott }\end{array}$ & $\begin{array}{l}\text { Building Research Eth- } \\
\text { ics Capacity in Post- } \\
\text { Communist Countries: } \\
\text { Experience of Two Fog- } \\
\text { arty Training Programs }\end{array}$ \\
\hline $\begin{array}{l}\text { Henry Silverman, Hillary } \\
\text { Edwards, Adil Shamoo, } \\
\text { and Amal Matar }\end{array}$ & $\begin{array}{l}\text { Enhancing Research Ethics } \\
\text { Capacity in the Middle } \\
\text { East: Experience and } \\
\text { Challenges of a Fogarty- } \\
\text { Sponsored Training } \\
\text { Program }\end{array}$ \\
\hline Sana Loue and Bebe Loff & $\begin{array}{l}\text { Mentoring International } \\
\text { Research Ethics Train- } \\
\text { ees: Identifying Best } \\
\text { Practices }\end{array}$ \\
\hline $\begin{array}{l}\text { Henry Silverman, Martin } \\
\text { Strosberg, Florencia Luna, } \\
\text { Sean Philpott, and Cheryl A. } \\
\text { Hemmerle }\end{array}$ & $\begin{array}{l}\text { An Analysis of Online } \\
\text { Courses in Research } \\
\text { Ethics in the Fogarty- } \\
\text { Sponsored Bioethics } \\
\text { Training Programs }\end{array}$ \\
\hline $\begin{array}{l}\text { Jonathan Fix, Jere Odell, } \\
\text { Barbara Sina, Eric M. Meslin, } \\
\text { Ken Goodman, and Ross } \\
\text { Upshur }\end{array}$ & $\begin{array}{l}\text { A Bibliometric Analysis } \\
\text { of an International } \\
\text { Research Ethics Trainee } \\
\text { Program }\end{array}$ \\
\hline \multicolumn{2}{|c|}{ JERHRE 9.2} \\
\hline $\begin{array}{l}\text { Martin A. Strosberg, Eu- } \\
\text { genijus Gefenas, and Andrei } \\
\text { Famenka }\end{array}$ & $\begin{array}{l}\text { Research Ethics Review: } \\
\text { Identifying Public Policy } \\
\text { and Program Gaps }\end{array}$ \\
\hline $\begin{array}{l}\text { Amal Matar, Sam Garner, } \\
\text { Joseph Millum, Barbara } \\
\text { Sina, and Henry Silverman }\end{array}$ & $\begin{array}{l}\text { Curricular Aspects of } \\
\text { the Fogarty Bioethics } \\
\text { International Training } \\
\text { Programs }\end{array}$ \\
\hline
\end{tabular}

(Continued)

Journal of Empirical Research on Human Research Ethics, VoL. 9, No. 2, PP. 1-2. PRINT ISSN 1556-2646, ONLINE ISSN 1556-2654. (๐) 2014 By JOAN SIEBER. ALL RIGHTS RESERVED. PLEASE DIRECT ALL REQUESTS FOR PERMISSIONS TO PHOTOCOPY OR REPRODUCE ARTICLE CONTENT THROUGH THE UNIVERSITY OF CALIFORNIA PRESS'S RIGHTS AND PERMISSIONS WEBSITE, HTTP://WWW.UCPRESSJOURNALS.COM/REPRINTINFO.ASP. DOI: $10.1525 /$ jer.2014.9.2.1 
BOX 1. (Continued)

\begin{tabular}{cc}
\hline Paul Ndebele, Douglas Was- & Research Ethics Capacity \\
senaar, Solomon Benatar, & Building in Sub-Saharan \\
Theodore Fleischer, Mariana & Africa: A Review of NIH \\
Kruger, Clement Adebamo- & Fogarty-Funded \\
wo, Nancy Kass, Eric M. & Programs 2000-2012 \\
Meslin, and Adnan Hyder & \\
Joseph Ali, Nancy E. Kass, & Evaluating International \\
Nelson K. Sewankambo, & Research Ethics Capacity \\
Tara D. White, and Adnan A. & Development: An Empiri- \\
Hyder & cal Approach \\
Bridget Pratt, Cassandra Van, & Fogarty Bioethics Training \\
Yali Cong, Harun Rashid, & Programs in the Asia- \\
Nandini Kumar, Aasim & Pacific: The Merging of \\
Ahmad, Ross Upshur, and & Cultures \\
Bebe Loff & \\
Bridget Pratt, Cassandra Van, & Perspectives from South \\
Emily Trevorrow, and & and East Asia on Clinical \\
Bebe Loff & and Research Ethics: \\
& A Literature Review \\
Carla Saenz, Elizabeth & Twelve Years of Fogarty- \\
Heitman, Florencia Luna, & Funded Bioethics \\
Sergio Litewka, Kenneth W. & Training in Latin \\
Goodman, and & America and the \\
Ruth Macklin & Caribbean: Achieve- \\
& ments and Challenges \\
\hline
\end{tabular}

In the present issue:

- Strosberg et al. describe a framework for identifying the policy and program gaps in research ethics systems, drawing on their work with trainees in the post-Soviet countries of Eastern Europe.

- Matar et al. survey the curricula content, trainee and faculty characteristics, and special challenges faced in designing culturally sensitive and contextually relevant research ethics education programs.

- Ndebele et al. describe the research ethics capacity built in Sub-Saharan Africa in the context of the challenges faced by the continent.

- Ali et al. present a tool developed to evaluate the impact of ethics training on African grantees that can readily be adapted to other contexts.

- Pratt et al. present a qualitative analysis of interviews describing the impact of research ethics education and the challenges Asian trainees face incorporating research ethics into institutional practice.

- A second paper by Pratt et al. examines the research ethics literature from Bangladesh, China, India, and Pakistan, and explores how religious, social, and cultural norms affect the interpretation of research ethics and the application of international standards in these countries.

- Finally, Saenz et al. analyze the achievements and challenges faced by training programs in Latin America and the Caribbean.

These papers represent the emergence of a community of practice for international research ethics education. They present detailed local knowledge, lessons learned, novel tools, and needs analyses, which may inform others who work in research and research ethics in LMICs.

Disclaimer: The opinions expressed are the authors' own. They do not reflect any position or policy of the National Institutes of Health, US Public Health Service, or Department of Health and Human Services.

\section{Author Note}

Address correspondence to: Joseph Millum: joseph. millum@nih.gov, or Barbara Sina: sinab@mail.nih.gov.

\section{Authors' Biographical Sketches}

Joseph Millum serves as a liaison between the Clinical Center Department of Bioethics and the Division of International Science Policy, Planning, and Evaluation at the Fogarty International Center, where he provides ethics consultation and educational support. His current research focuses on the rights and responsibilities of parents, global justice and bioethics, priority setting for global health, and international research ethics.

Barbara Sina is the Program Officer for the International Research Ethics Education and Curriculum Development Program in the Division of International Training and Research, Fogarty International Center, National Institutes of Health. 